\title{
The use of children's stories in nursing care for the child: an integrative review
}

\author{
O uso de histórias infantis no cuidado de enfermagem à criança: revisão integrativa \\ El uso de historias infantiles en la atención de enfermería al niño: revisión integradora
}

'Universidade Federal do Rio Grande do Sul. Porto Alegre. Rio Grande do Sul. Brasil.

\author{
Jeanine Porto Brondani' \\ ORCID: 0000-0002-3061-4199 \\ Eva Neri Rubim Pedro' \\ ORCID: 0000-0003-0683-6813
}

How to cite this article:

Brondani JP, Pedro ENR. The use of children's stories in nursing care for the child: an integrative review.

Rev Bras Enferm. 2019;72(Suppl 3):333-42. doi: http://dx.doi.org/10.1590/0034-7167-2018-0456

\section{Corresponding Author:}

Jeanine Porto Brondani

E-mail: jeaninebrondani@yahoo.com.br

Submission: 06-08-2018 Approval: 02-18-2019

\section{ABSTRACT}

Objective: To identify how children's stories can be used in child care. Method: Integrative literature review, conducted in databases between 2000 and 2018, in three languages. Full research articles were included that agreed with the following question: "How can children's stories be used in child care?". Results: From the analysis of 16 selected articles, three categories emerged: The use of stories in the hospital; Specialized nursing intervention; and Stories in the educational dimension. Final considerations: Evidence shows benefits to children, families, institutions and nursing. The use of children's stories as a care intervention can occur in different situations and settings, values; boosts bonds, reduces anxiety in children and families, encourages children's participation in care, and promotes health education. It is a low-cost and still incipient strategy in nursing. Descriptors: Juvenile literature; Child; Nursing; Play and playthings; Nursing Care.

\section{RESUMO}

Objetivo: Identificar como as histórias infantis podem ser utilizadas no cuidado à criança. Método: Revisão integrativa da literatura, realizada em bases de dados, entre 2000 e 2018 , em três idiomas. Foram incluídos artigos de pesquisa disponíveis na íntegra e que estavam de acordo com a seguinte questão: "Como as histórias infantis podem ser utilizadas no cuidado à criança?". Resultados: A partir da análise de 16 artigos selecionados, emergiram três categorias: $O$ uso de histórias no hospital; Intervenção de enfermagem especializada; e Histórias na dimensão educativa. Considerações finais: As evidências apontam benefícios às crianças, às famílias, às instituições e à Enfermagem. $\mathrm{O}$ uso de histórias infantis como intervenção de cuidado pode ocorrer em diferentes situações e cenários, valoriza e estimula vínculos, reduz ansiedade das crianças e familiares, estimula a participação das crianças no cuidado, e promove educação em saúde. É uma estratégia de baixo custo e ainda incipiente na Enfermagem.

Descritores: Literatura infantojuvenil; Criança; Enfermagem; Jogos e Brinquedos; Cuidado de Enfermagem.

\section{RESUMEN}

Objetivo: Identificar cómo las historias infantiles se pueden utilizar en la atención al niño. Método: Revisión integradora de la literatura, realizada en bases de datos, entre 2000 y 2018, en tres idiomas. Se incluyeron artículos de investigación disponibles en su totalidad y que estaban de acuerdo con la siguiente pregunta: ¿Cómo las historias infantiles pueden ser utilizadas en la atención al niño? Resultados: A partir del análisis de 16 artículos seleccionados surgieron tres categorías: El uso de historias en el hospital; Intervención de enfermería especializada; e Historias en la dimensión educativa. Consideraciones finales: Las evidencias apuntan beneficios a los niños, a las familias, a las instituciones y a la Enfermería. El uso de historias infantiles como intervención de atención puede ocurrir en diferentes situaciones y escenarios, pues valoriza y estimula vínculos, reduce la ansiedad de los niños y sus familiares, estimula la participación de los niños en la atención, y promueve educación en Salud. Es una estrategia de bajo costo, y aún incipiente en la Enfermería. Descriptores: Literatura Infanto - Juvenil; Enfermería; Niño; Juego e implementos de juego; Atención de Enfermería. 


\section{INTRODUCTION}

Nursing care in children's area integrates specific knowledge to assure quality of the care and skills that allow the child and the family to feel participants, in other words, that there are good conditions of interaction during the care ${ }^{(1)}$.

One of the conditions that favor interaction is play, which is the child's basic needs. In nursing, the practice of play is stimulated in the daily routine and, whenever possible, used as intervention strategy in the care. They have been extensively studied, both as free play and the relationship with health promotion and development, as well as interventions that have improved. Among them, the use of stories and therapeutic play (TP) stand out as strategies capable of interfering in a positive way in the child's perception about the health-disease process and about nursing care $^{(2-7)}$. TP is classified in instructional, physiological and dramatic functions ${ }^{(2)}$, and can be used in different care settings, allowing the child to better express their perceptions and needs $s^{(3)}$.

Stories as a mediating intervention in the care process may be only a recreational reading, boosts the imagination and helps the child to mitigate the treatment consequences, but can also be used as a therapeutic and structured reading, in order to intervene in part of the care. In this case, it can bring to nursing, child and family, the improvement in the acceptance of painful procedures, understanding of the health-disease process, trust in the professional, acceptance of treatments and serves as a tool for the health and research ${ }^{(4-7)}$. The success of this intervention depends on adequate planning and the professional's ability to use the technique. The choice of patient, book, environment and activity evaluation have been described as important in the applicability and acceptance of children ${ }^{(8)}$.

It is known the problems that professionals face in the health services, such as the lack of employees, the high number of users, the exhaustion of work. It is also known that the time for storytelling can be referred to as a difficulty. However, moments of interaction may be very opportune for the use of light technology in health, because efficient communication and qualified listening allow the identification of needs that value the particularities and subjectivities, helping the professional in the knowledge and interventions in the context of people, capturing singularities, building bonds and producing care ${ }^{(9)}$. Thus, the use of stories and play to care for children respects the Child and the Adolescent rights ${ }^{(10)}$, as it allows them to express opinions, learn, participate in the therapeutic process, develop, feel safe and have fun. The use of stories can bring children closer to health professionals and also the family ${ }^{(11)}$.

Dramatic, or playful, jokes are those that represent everyday life, and through plays or stories, children can play roles and learn. They are able to develop socialization, creativity, cooperation, self-awareness and still have therapeutic value ${ }^{(12)}$. In view of the importance of this activity, the Conselho Federal de Enfermagem (Federal Nursing Council), in Resolution 546/2017, determines that the therapeutic technique is the responsibility of the nursing team in the care for the child and the family, as well as, when used, be contemplated in the nursing process stages ${ }^{(13)}$.

In Brazil, there is an extensive scientific production that deals with playing in care practices. However, the use of books or stories as a tool to care for children was little found. Therefore, it lacks studies that best demonstrate how this strategy can collaborate and/or interfere in nurses' care and work process. Thus, this study sought to answer the following research question: "How can children's stories be used in child care?".

\section{OBJECTIVE}

To identify, through literature review, how children's stories can be used in child care.

\section{METHOD}

This is an integrative review of literature, consisting of six stages: hypothesis definition and research question elaboration, literature search, data collection and categorization of studies, critical analysis of the studies included in the review, interpretation of results and presentation of the review. This method seeks to identify the evidences in the scientific productions and to discuss them according to the object of study ${ }^{(14)}$.

The searches occurred in June 2016 and were updated in April and May 2018, the period between 2000 and 2018 being based on the Medical Literature Analysis and Retrieval System Online (MEDLINE/PubMed), Web of Science, Cumulative Index to Nursing and Allied Health Literature (CINAHL), Scopus Elsevier, Latin American \& Caribbean Literature in Health Sciences (LILACS), Medical Literature Analysis (MEDLINE), Base de dados da Enfermagem (BDENF) through Virtual Health Library (VHL) portal and Scientific Electronic Library Online (SciELO). The selected languages were: English, Portuguese and Spanish, using the descriptors, keywords and Mesh Terms: Play Therapy, Biblioterapy, Juvenile Literature, Child, Nursing, Play and Playthings, Education, Pedriatric Nursing and Storytelling in different combinations with the Boolean operators AND and OR.

To be included, the article needed to be available in its full, to address nursing care for children from zero to 12 years of age, be performed by professionals and/or nursing students and refer to the use of children's stories. Experience reports, integrative reviews, and descriptive and/or theoretical articles were excluded. These eligibility criteria are justified by the research's methodological rigor and presentation of the necessary evidence to integrative review studies ${ }^{(14)}$.

The initial screening was done by reading the titles and abstracts, separating the possible articles of inclusion in the themes: health education, therapeutic plays and bibliotherapy. Afterwards, the articles were read in full, in order to separate those that contained the use of stories in child care.

After the final selection, all studies were analyzed from the search in the contents of articles of evidence that identified how the care for children occurred using stories; in which setting; at which moment of the care process; how this resource was used; and what the repercussions for the child and professionals due to the use of this strategy.

\section{RESULTS}

There were 493 articles in the VHL/LILACS/MEDLINE, 39 in the Web of Science, 131 in PubMed and 503 in CINAHL, Scopus 120 and SciELO 351, totaling 1,637 articles. 
After applying the inclusion and exclusion criteria, the final sample consisted of 16 articles, organized in Flowchart 1.

Of the 16 articles found, nine are in international journals and seven in national journals. Although the search period was established in 18 years, only in the last ten years has there been research involving storytelling, two articles in 2008, one article in 2009, two articles in 2010, two articles in 2011, an article in 2013, two articles in 2014, two articles in 2015, two articles in 2016 and two articles in 2017. The majority of the studies, nine articles, were published in the last five years, which shows more attention to the topic. The Revista Gaúcha de Enfermagem has four articles, followed by Pediatric Nursing, with two and the others with one article each.

From the organization and grouping of the findings, the following categories: "Storytelling in the hospital" grouping nine articles, "Specialized nursing intervention", four, and "Storytelling in the educational dimension", three.

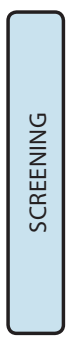

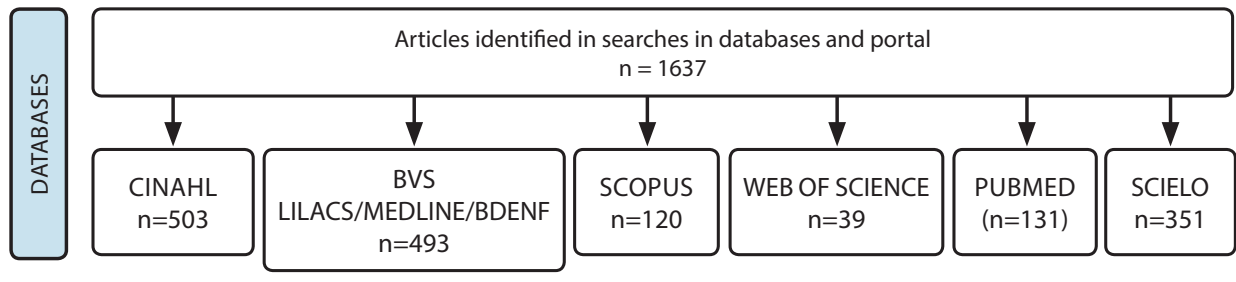
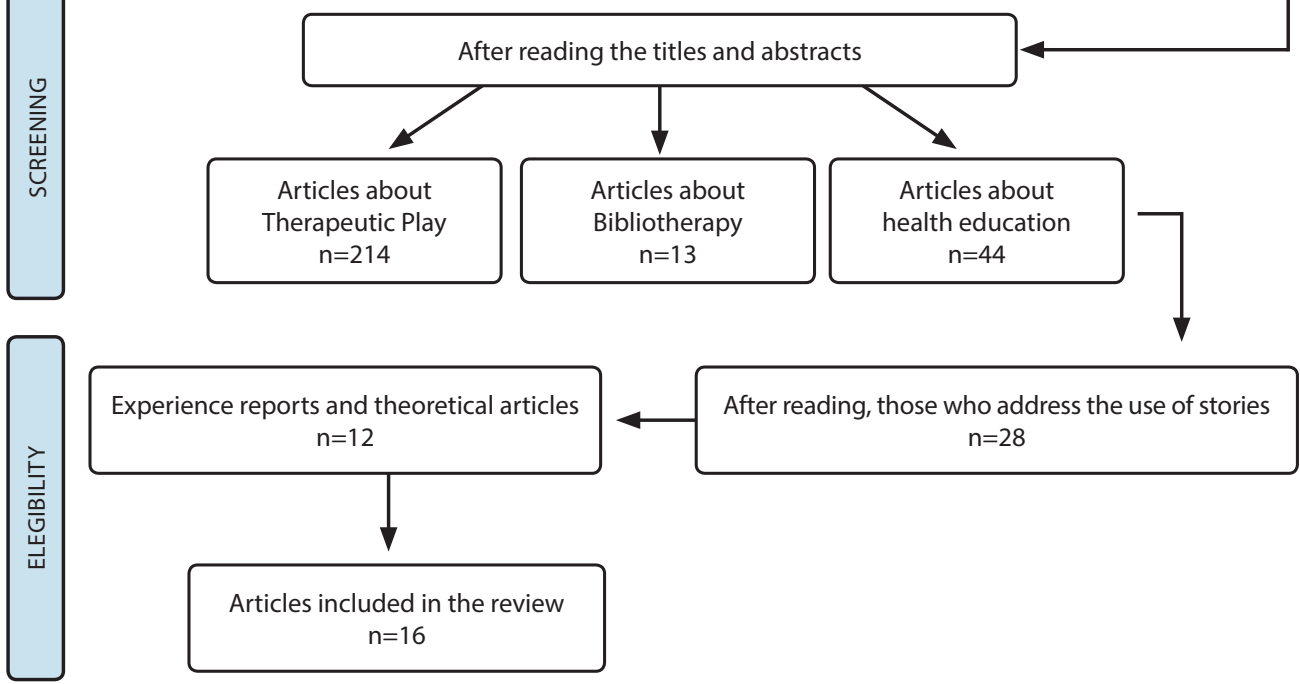

Figure 1- Flowchart of screening and eligibility of review articles

\section{Storytelling in the hospital}

The nursing approach in the selected literature by using stories involved venipuncture for the use of medications and serum therapy. It also involved preparation for surgery in two studies,

Chart 1 - Organization of articles included in the review according to title, year, country, journal, objective and results, 2000-2018

\begin{tabular}{|c|c|c|c|c|}
\hline No & Title of the article selected & $\begin{array}{l}\text { Year/ } \\
\text { Country/ } \\
\text { Journal }\end{array}$ & Objective & Results \\
\hline A1 & $\begin{array}{l}\text { The effect of storytelling in a } \\
\text { play therapy on Anxiety level } \\
\text { in pre-school children during } \\
\text { Hospitalization in the general } \\
\text { hospital of Buton }\end{array}$ & $\begin{array}{l}2017 / \\
\text { Indonesia/ } \\
\text { Public Health of } \\
\text { Indonesia }\end{array}$ & $\begin{array}{l}\text { To determine the effect of } \\
\text { storytelling on the level of } \\
\text { anxiety in preschoolers during } \\
\text { hospitalization. }\end{array}$ & $\begin{array}{l}\text { It showed a significant reduction in anxiety } \\
\text { levels in children during hospitalization. } \\
\text { Stories can be applied by Nursing to reduce } \\
\text { anxiety in hospitalized children. }\end{array}$ \\
\hline A2 & $\begin{array}{l}\text { Stories That Heal: } \\
\text { Understanding the Effects of } \\
\text { Creating Digital Stories With } \\
\text { Pediatric and Adolescent/ } \\
\text { Young Adult Oncology } \\
\text { Patients }\end{array}$ & $\begin{array}{l}2017 / \\
\text { Canada/ } \\
\text { Journal of Pediatric } \\
\text { Oncology Nursing }\end{array}$ & $\begin{array}{l}\text { To determine and understand how } \\
\text { digital stories can be used as tools } \\
\text { in caring for children with cancer. }\end{array}$ & $\begin{array}{l}\text { It pointed to an alternative path to very } \\
\text { complex overcoming problems without the } \\
\text { traditional approach to psychotherapy or } \\
\text { other common therapeutic interventions. }\end{array}$ \\
\hline A3 & $\begin{array}{l}\text { Play distraction versus } \\
\text { pharmacological treatment } \\
\text { to reduce anxiety levels in } \\
\text { children undergoing day } \\
\text { surgery: a randomized } \\
\text { controlled non-inferiority trial }\end{array}$ & $\begin{array}{l}2016 \\
\text { United Arab } \\
\text { Emirates and } \\
\text { Jordan/ Child: } \\
\text { care, health and } \\
\text { development }\end{array}$ & $\begin{array}{l}\text { To explore the efficiency of } \\
\text { narrative, imaging and painting } \\
\text { as an anxiolytic intervention } \\
\text { compared to pharmacology, } \\
\text { traditional, pre-medication } \\
\text { technique. }\end{array}$ & $\begin{array}{l}\text { The use of story and the use of medication } \\
\text { reduced anxiety in very similar proportions, } \\
\text { which shows that stories can be used to } \\
\text { reduce anxiety in children who need to } \\
\text { perform surgeries. }\end{array}$ \\
\hline A4 & $\begin{array}{l}\text { Using Therapeutic Toys } \\
\text { to Facilitate Venipuncture } \\
\text { Procedure in Preschool } \\
\text { Children }\end{array}$ & $\begin{array}{l}\text { 2016/ } \\
\text { Brazil/ Pediatric } \\
\text { Nursing }\end{array}$ & $\begin{array}{l}\text { To study the efficacy of therapeutic } \\
\text { plays during venipuncture } \\
\text { procedures in children. }\end{array}$ & $\begin{array}{l}\text { It demonstrated reduced expression of fear, } \\
\text { presence of smile, jokes and conversations } \\
\text { after the procedure. }\end{array}$ \\
\hline
\end{tabular}




\begin{tabular}{|c|c|c|c|c|}
\hline No & Title of the article selected & $\begin{array}{l}\text { Yearl } \\
\text { Country/ } \\
\text { Journal }\end{array}$ & Objective & Results \\
\hline A5 & $\begin{array}{l}\text { Crianças e o conhecimento de } \\
\text { si próprias a partir de histórias } \\
\text { infantis }\end{array}$ & $\begin{array}{l}\text { 2015/ } \\
\text { Brazil/ Rev Enferm } \\
\text { UFSM }\end{array}$ & $\begin{array}{l}\text { To check the children's knowledge } \\
\text { of themselves by telling children's } \\
\text { stories with specific health topics. }\end{array}$ & $\begin{array}{l}\text { It promoted education in health and mental } \\
\text { health and can be used as a complementary } \\
\text { alternative to the treatment of children with } \\
\text { mental disorders. }\end{array}$ \\
\hline A6 & $\begin{array}{l}\text { What Is It Like to Be a Child } \\
\text { with Type } 1 \text { Diabetes Mellitus? }\end{array}$ & $\begin{array}{l}\text { 2015/ } \\
\text { Brazil/ Pediatric } \\
\text { Nursing }\end{array}$ & $\begin{array}{l}\text { To understand what it's like to be a } \\
\text { child with Type } 1 \text { Diabetes Mellitus } \\
\text { from a child's perspective and } \\
\text { explore factors that interfere with } \\
\text { disease management. }\end{array}$ & $\begin{array}{l}\text { It facilitated children's learning about the } \\
\text { disease and complications. }\end{array}$ \\
\hline A7 & $\begin{array}{l}\text { Intervenção lúdica a crianças } \\
\text { com doença crônica: } \\
\text { promovendo o enfrentamento }\end{array}$ & $\begin{array}{l}\text { 2014/ } \\
\text { Brazil/ Rev Gaúcha } \\
\text { Enferm }\end{array}$ & $\begin{array}{l}\text { To analyze the effects of the manual } \\
\text { "Como Hóspede no Hospital" activities } \\
\text { on the process of coping with } \\
\text { children affected by chronic diseases. }\end{array}$ & $\begin{array}{l}\text { It expanded the child's participation in the } \\
\text { health-disease process and in the treatment, } \\
\text { promoting the acquisition of coping } \\
\text { strategies. }\end{array}$ \\
\hline A8 & $\begin{array}{l}\text { Little people, big lessons: } \\
\text { An innovative strategy to } \\
\text { develop interpersonal skills } \\
\text { in undergraduate nursing } \\
\text { students }\end{array}$ & $\begin{array}{l}\text { 2014/ } \\
\text { Australia } \\
\text { Nurse Education }\end{array}$ & $\begin{array}{l}\text { To explore the applications of } \\
\text { interpersonal theory. To describe } \\
\text { a learning strategy for theory and } \\
\text { equip nurses and students to work } \\
\text { with children. }\end{array}$ & $\begin{array}{l}\text { There was improvement in the relationship } \\
\text { between theory and practice, information } \\
\text { processing and learning on children's } \\
\text { language. There was increased confidence in } \\
\text { a motivating way, arousing the curiosity of } \\
\text { nursing students. }\end{array}$ \\
\hline A9 & $\begin{array}{l}\text { A história infantil como recurso } \\
\text { na compreensão do processo } \\
\text { saúde-doença pela criança } \\
\text { com HIV }\end{array}$ & $\begin{array}{l}\text { 2013/ } \\
\text { Brazil/ Rev Gaúcha } \\
\text { Enferm }\end{array}$ & $\begin{array}{l}\text { To analyze how a children's } \\
\text { story containing issues related } \\
\text { to HIV/AIDS contributes to the } \\
\text { understanding of the health- } \\
\text { disease process by the child with } \\
\text { HIV. }\end{array}$ & $\begin{array}{l}\text { It demonstrated that it is possible to talk } \\
\text { to the child with HIV about her situation } \\
\text { without revealing the diagnosis. It serves to } \\
\text { stimulate health education, understanding } \\
\text { health status, participation in the therapeutic } \\
\text { process, acceptance of treatment, and living } \\
\text { with other children in a similar situation. }\end{array}$ \\
\hline A10 & $\begin{array}{l}\text { Promoção em saúde mental: } \\
\text { a enfermagem criando e } \\
\text { intervindo com histórias } \\
\text { infantis }\end{array}$ & $\begin{array}{l}\text { 2011/ } \\
\text { Brazil/ Rev Gaúcha } \\
\text { Enferm }\end{array}$ & $\begin{array}{l}\text { To check the knowledge } \\
\text { (acknowledgment) of the emotions } \\
\text { of children, through specific stories } \\
\text { for health. }\end{array}$ & $\begin{array}{l}\text { Storytelling as a child mental health care } \\
\text { strategy was able to access complex, } \\
\text { difficult-to-understand feelings for the child, } \\
\text { helping them to elaborate on deep issues } \\
\text { and verbalize their fears, anguish, and joys. }\end{array}$ \\
\hline A11 & $\begin{array}{l}\text { Lectura de cuentos infantiles } \\
\text { como estrategia de } \\
\text { humanización en el cuidado } \\
\text { del niño acamado en ambiente } \\
\text { hospitalario }\end{array}$ & $\begin{array}{l}2011 \\
\text { Brazil/ } \\
\text { Invest Educ Enferm }\end{array}$ & $\begin{array}{l}\text { To evaluate the reading of } \\
\text { children's stories as a strategy for } \\
\text { the humanization of hospitalized } \\
\text { child care. }\end{array}$ & $\begin{array}{l}\text { All children and their caregivers showed } \\
\text { themselves to be participative and cheerful. } \\
\text { There was identification with the characters } \\
\text { of the stories and improvement in the } \\
\text { treatment. Encouraged the habit of reading. }\end{array}$ \\
\hline A12 & $\begin{array}{l}\text { Olho vivo: analisando a } \\
\text { acuidade visual das crianças } \\
\text { e o emprego do lúdico no } \\
\text { cuidado de enfermagem }\end{array}$ & $\begin{array}{l}2010 / \\
\text { Brazil/ } \\
\text { Esc Anna Nery Rev } \\
\text { Enferm }\end{array}$ & $\begin{array}{l}\text { To early detect visual deficit in } \\
\text { school children and promotion } \\
\text { of visual health through ludic } \\
\text { activities. }\end{array}$ & $\begin{array}{l}\text { Ludic activities were decisive for } \\
\text { understanding eye care, and encouraged } \\
\text { the participation of children in visual } \\
\text { assessment. }\end{array}$ \\
\hline A13 & $\begin{array}{l}\text { Utilização do brinquedo } \\
\text { terapêutico na assistência à } \\
\text { criança hospitalizada }\end{array}$ & $\begin{array}{l}2010 / \\
\text { Brazil/ } \\
\text { Rev. Bras. Ed. Esp., } \\
\text { Marília }\end{array}$ & $\begin{array}{l}\text { To use the therapeutic play as a } \\
\text { resource in relieving the child's } \\
\text { real and unconscious tensions } \\
\text { regarding hospitalization. }\end{array}$ & $\begin{array}{l}\text { TP (Therapeutic Play) before surgery was a } \\
\text { health education facilitator for children in } \\
\text { need of surgery. }\end{array}$ \\
\hline A14 & $\begin{array}{l}\text { A mediação de leitura como } \\
\text { recurso de comunicação com } \\
\text { crianças Hospitalizadas }\end{array}$ & $\begin{array}{l}\text { 2009/ } \\
\text { Brazil/ Rev Latino- } \\
\text { am Enferma-gem }\end{array}$ & $\begin{array}{l}\text { To understand the extent to which } \\
\text { the mediation of stories proposed } \\
\text { by the Biblioteca Viva em Hospitais } \\
\text { (Living Library in Hospitals) Project } \\
\text { can be a means of communication } \\
\text { with the hospitalized child. }\end{array}$ & $\begin{array}{l}\text { Gerou possibilidade terapêutica e } \\
\text { educativa, pois além de oferecer à criança } \\
\text { a oportunidade de entender o que } \\
\text { ocorria, também melhorou a aceitação de } \\
\text { procedimentos. }\end{array}$ \\
\hline A15 & $\begin{array}{l}\text { Pilot Testing Okay With } \\
\text { Asthma: } \\
\text { An Online Asthma } \\
\text { Intervention for } \\
\text { School-Age Children }\end{array}$ & $\begin{array}{l}\text { 2008/ } \\
\text { United States/The } \\
\text { Journal of School } \\
\text { Nursing }\end{array}$ & $\begin{array}{l}\text { To know the effectiveness of using } \\
\text { the Okay With Asthma program } \\
\text { to understand the attitudes of } \\
\text { children with asthma. }\end{array}$ & $\begin{array}{l}\text { There has been significant improvement in } \\
\text { knowledge about the disease and on what } \\
\text { self-care attitudes can be taken. }\end{array}$ \\
\hline A16 & $\begin{array}{l}\text { Using puppetry to elicit } \\
\text { children's talk for research }\end{array}$ & $\begin{array}{l}\text { 2008/ } \\
\text { Canada/ } \\
\text { Nursing Inquiry }\end{array}$ & $\begin{array}{l}\text { To explore the use of puppets and } \\
\text { describe how they can be used to } \\
\text { obtain search data. }\end{array}$ & $\begin{array}{l}\text { The storytelling using puppets was based } \\
\text { on the simulation of care situations, } \\
\text { respecting the child's time, language and } \\
\text { development. It can be used in different } \\
\text { researches in nursing. }\end{array}$ \\
\hline
\end{tabular}


perception about treatment, free play, humanization and communication. The main setting was the children's hospital, in the pediatric hospitalization units.

The hospital environment is stressful for children because of sounds, unknown people, painful procedures, tension and various interventions that generate distress, resistance to treatment and high levels of anxiety. Articles $A 1^{(15)}$ and $A 3^{(16)}$ address the effects of storytelling on anxiety in children as measured by scales and statistical tests. The results of $A 1^{(15)}$ showed that there was a significant reduction in anxiety in children who received interventions through fairy tale narration, which shows that storytelling is a tool that can be used by nursing in reducing anxiety hospitalized children ${ }^{(15)}$. In $A 3^{(16)}$, the storytelling dealt with narration of a specific text about the surgery, which presented the child with the equipment, situations and professionals. The use of this intervention reduced anxiety in a very similar way to the effects of the medication. The article highlights the importance of storytelling in the preparation of children for surgery as a noninvasive and minimizing side effects strategy ${ }^{(16)}$. A1 $13^{(17)}$ studies how the contact with surgical tools in sessions of instructional TP had repercussion in the preparation of children before the surgery for correction of the cleft palate. Storytelling and dramatization about the situation was used to simulate the necessary condition for handling playthings and assisting in understanding. The result showed TP sessions before surgery was an excellent facilitator to health education. Likewise, $A 4^{(18)}$ studied the application of instructional TP associated with storytelling in venipuncture for medication and serum therapy. The results showed the reduction of the expression of fear, and the presence of smile, jokes and conversations after the procedure. The relatives expressed satisfaction with playful interventions, referring to greater tranquility and participation. The study emphasized that the knowledge of the child's cognitive development phase in the planning of the activity is fundamental for the success of this technology ${ }^{(18)}$.

$A 7^{(6)}$ showed how a manual called "Como Hóspede no Hospital", created to address recurrent hospitalizations in chronic disease, assisted in understanding the health-disease process and in the child's participation in the therapeutic process. Children were well accepted for hospital activities and were able to talk about living with chronic illness and hospitalization, promoting the acquisition of coping strategies ${ }^{(6)}$.

The Biblioteca Viva em Hospitais (Living Library in Hospitals) Project, discussed in A14 ${ }^{(19)}$, is another work on the relationship of literature, integrating caregiving. Fairy tales were used to promote health, play, and stimulation of the imaginary. Based on humanization and comprehensiveness, it generated a therapeutic and educational possibility, because in addition to offering the child the opportunity to understand what happened, it also improved the acceptance of procedures. Similarly, $\mathrm{A} 11^{(20)}$ addressed reading for bedridden children with significant movement limitations. They showed themselves to be participative, cheerful, identified with the stories and their companions were satisfied. It was considered that the bedside reading is a strategy of humanization of the care that promotes identification with stories situations and, with this, expression of feelings, thoughts and improvement in health ${ }^{(20)}$.

With regard to digital stories, $\mathrm{A} 2^{(21)}$ aimed to determine and understand how digital stories can be used as tools in the care for children with cancer. Construction of stories by children and their parents about their lives has contributed to the sharing of experiences, helping to speak differently and to listen even more. Language, images, and music present in the stories seemed to produce effects that contributed to the ability to explain their experiences. It is a different therapeutic resource that allowed to perceive questions that were not possible to be approached by the psychologists, because the simple fact of speaking of itself through a story accessed emotional components present in the fantasy of children very little accessed by the professionals. Digital stories provided a pathway for very complex feelings processing problems without the traditional approach to psychotherapy or other common therapeutic interventions ${ }^{(21)}$.

Puppets are also widely used for storytelling, and have proven efficacy in communicating. However, details of the use of the technique are still few in nursing. $A 16^{(5)}$ describes how this technique can be used as a communication tool to obtain research data. The interview with the use of puppet took place in the hospital and, simulating the researcher, asking the questions, and talking with the child, was able to leave the child at ease to obtain data. The study also emphasizes that the child can choose the puppet to answer the questions and talk about their perceptions, noting that there is still the possibility of both using puppets to talk. Puppets need to look like a child for identification to occur. The environment needs to be adequate, in addition to the professional needs to be trained. Storytelling relevance by using puppets is based on the simulation of care situations, respecting the child's time, language and cognitive development to obtain the data necessary for the different researches in nursing ${ }^{(5)}$. Clinical intervention has different objectives of the research, however, when interviewing, it is sought to gather information for a goal, so this study deserves to be highlighted.

\section{Specialized nursing intervention}

Stories in this category aggregated studies performed in specialized and outpatient services. The stories were child-specific, related to emotional and behavioral disorders, HIV in childhood and Diabetes Mellitus.

Behavioral approaches in Centros de Apoio Psicossocial Infantil (Child Psychosocial Support Centers) are present in mental health articles found in this review, appearing in $A 5^{(7)}$ and $A 10^{(19)}$. In $A 5^{(7)}$, specific stories were used as triggers in the approach on the themes: anxiety/nervousness, happiness, annoyance, irritation/anger, tranquility, sadness and fear. The storytelling group was shown to be a space for mental health promotion, which made it possible to confront and elaborate the psychological processes of children. The recognition of emotions by children through the stimulation of storytelling showed that they, when used with specific purpose, are configured as a strategy of care in Child Mental Health. Beware of accessing complex and difficultto-understand feelings for the child, helping them to elaborate on deep issues and verbalize their fears, anguish, and joys ${ }^{(7)}$. On the other hand, $A 10^{(22)}$ showed that self-recognition through the use of elaborate stories about the everyday experiences of children with mood and behavior disorders has assumed the role of educating in health and promoting mental health through 
direct identification of children through. Thus, storytelling can be understood as an alternative nursing action and complementary to the treatment of children with mental disorders ${ }^{(22) .}$

In the case of HIV, present in $\mathrm{A9}^{(4)}$, the analysis of the use of a specific story about children living with AIDS, created from elements on the health-disease process, showed that the use of story was very profitable, because it gave the expression of thoughts, feelings about their health states and also allowed the integration between them. In addition, the identification with the characters of the story revealed an interest in learning about the theme and mobilized a process of elaboration of feelings related to the context of each one. The results indicated that storytelling is a viable care tool to initiate the process of disclosure of the diagnosis of HIV/AIDS for children and adolescents, as well as for health education for the whole family, and can be used in schools and health services ${ }^{(4)}$.

Another chronic disease that affects and significantly affects the life of children and adolescents is Type $1 \mathrm{DM} . \mathrm{A} 6^{(23)}$ is a study about the living of the child with DM, showing what it is like to be a child in this condition, its limits, fears, relationships and care. Through the construction of a story, scenery and puppets, children dramatized everyday situations. The strategy was effective in communicating with children as it encouraged the expression of their feelings, their understanding of the disease and helped them cope with the disease on a daily basis. The children's learning about the disease and complications ${ }^{(23)}$.

\section{Storytelling in the educational dimension}

Three articles dealt with health education through the use of stories, being one on nursing training and two on Nursing in School Health.

The development of interpersonal relationships necessary for child care is part of nursing training. Although the contents of interpersonal relations are in the curriculum of the nursing courses, most of the curricular practices prioritize the biological care, and the experiences and knowledge about these relationships often fall short of the desired one. $A 8^{(24)}$ explored the use of TP inserted in the simulation activities in the laboratory for nursing students to learn how to take care of children. For each doll was created a story that dealt with a real clinical situation. The results showed that the students were able to relate the theory to the practice, saying that it facilitated the processing of the information. In addition, they studied language and strategies to approach the child, generating trust in a motivating way, arousing curiosity ${ }^{(24)}$.

With regard to School Nursing, A12(25) aimed to detect early visual deficit in school children and to promote visual health through ludic activities. Through a specific story about eye care, staged with puppet support, and told in the children's school, an understanding of the necessity and importance of this assessment and of wearing glasses has been improved. The ludic activity was based on the commitment to make the child understand the actions of the professionals, to learn to self-care and still participate in the care actions. Storytelling was fundamental as a facilitating method for children's learning and, in this way, contributed to the promotion of health.

In A15 ${ }^{(26)}$, the objective was to identify the attitudes of children related to asthma from participating in the activities of a free educational program called "Okay With Asthm". The program addresses, through digital stories, daily occasions of a girl with asthma in various situations of daily life. After each story, there is a game with questions related to asthma and self-care. The results showed a significant improvement in knowledge about asthma, and a better performance in self-care attitudes. The study also highlights the importance of school nurses using this strategy to care for children ${ }^{(22)}$.

\section{DISCUSSION}

Nursing care, based on the use of stories, characterized different approaches that emphasized emotional care, coping, child participation in treatment, health education, expression of feelings and thoughts that enabled humanization, and play as basic needs of the child. Most of this practice was studied in a children's hospital. TP, associated with storytelling, as already highlighted, was an important technology for stress reduction, acceptance and participation in procedures. By dramatizing and handling some objects used for the care, children were able to process information that aided them in understanding what would be accomplished and in developing the bond with professionals $s^{(3)}$. Thus, even if the procedures are painful, such as venipuncture, playing as structured therapy, besides alleviating emotional demands, interferes with the physical condition by the direct connection of the emotional with the production of neurotransmitters ${ }^{(18)}$. Dramatic TP uses storytelling to assist the child in developing feelings and assisting expression. However, it can be observed that storytelling, associated with TP in the instructional modality, offered a new perspective on the procedure and surgery ${ }^{(2,18,27)}$. It cannot be said that it reduced pain, but certainly there is a new, more positive view that can help in the treatment and encourage the child, characterizing itself as a constructive strategy capable of assisting in the emotional recovery of the child. Therefore, it is an action of emotional care that allows for a more positive and less fearful experience in relation to the current and future illness, procedures and hospitalization situation ${ }^{(28)}$.

Among the fears of hospitalized children are pain, procedures, unknown persons and the environment. As a consequence, it can generate sleep disorders, aggression, inappetence and negatively interfere with recovery. Play and care with play techniques, which preferably involve the family, reduce these conditions, contributing to a better prognosis of children ${ }^{(28)}$. Given the increased use of controlled medications in children, dedicating time and using stories associated with tasks that relate to each case were care that had positive repercussions on children's thoughts, feelings and behavior. It is a large field of nursing practice that ranges from small children to adolescents ${ }^{(7,22)}$. Nurses who work in the emotional setting of emotion regulation, develop interactions directed to the management of the emotions of the child and his family, which is extremely important in the positive transformation of the emotional experience of fear ${ }^{(28)}$.

The simulation of the care situations present in the stories offered elements that are part of psychological scene of children in different ways, because they are possible representatives of their inner world, presenting them aspects known and also scary ${ }^{(29)}$. Consequently, it is possible to access the fantasy fields of children 
with care, delicacy and science, important characteristics in the care process in Nursing in Child Health. The approach was able to provide children with a space to elaborate their psychic processes, because during the development of the narrative, the child can take refuge to acquire the capacity to endure the difficulties experienced. Short stories prove to be material conducive to children's reflection and a rich research tool on the qualities of children's judgments ${ }^{(29)}$. In storytelling, the questions "What are the characters feeling, or how are they behaving? What did they learn?" are important for children's reflection that need to be mediated by a professional to process information that includes age, gender and the environment. The child's assessment of characters makes the books a viable tool for understanding complex feelings in childhood $^{(30)}$.

Reading mediation can be performed by different professionals, provided they are prepared. However, when it is necessary, the preparation for a particular nursing intervention requires the accomplishment by a professional, in view of the need for bonding and trust on the part of the child ${ }^{(31)}$. When this is not possible, the insertion of parents into the intervention can collaborate a lot, as long as they are trained by the nursing, as demonstrated in $A 3^{(16)}$. Therefore, giving access to books for children and reading with and for them are also important and necessary conditions for provision of care. Ludic and educational interventions are important in the comprehensive care for the child's and the adolescent's health, since they increase the care and promote autonomy. These are actions that go beyond providing instructions on the conduct with the treatment to be fulfilled(6).

Reading as an intervention humanizes the practice, as the storytelling facilitates the protagonism, the reception, to the extent that the mediation of reading in child care is stimulated in different spaces of care for the child, such as beds, corridors and lobbies, besides that the child can read with the professional or just listen. Depending on the purpose, the child has the freedom to choose the book or the moment of care which strategy will be used ${ }^{(32)}$. The strategy is fundamental when seeking comprehensive care, since health services are not only for healing, but also for development ${ }^{(31)}$. Thus, books can be used for children who are bedridden and/or limited in movement both to boost play and to intervene, since it is only necessary that the child is willing to participate ${ }^{(20)}$.

Storytelling contributes to increase the care for the child, generating positive consequences in the treatment. It may be an area still to be explored as a resource in children's health ${ }^{(30)}$, besides being useful to learn to live with the child with chronic illness $s^{(4,6,23)}$.

In the educational context, it is important that the health professional think about the child's care, going beyond the biological aspect and seeking to meet the demands of their development. Children with chronic diseases, such as asthma, DM, HIV, mood disorders and behavior, addressed in this review, often miss school and are deprived of living with their friends and colleagues. Ludic activities, school and family life revolve around health care and, often, fear of complications is present in their daily lives. Nurses who care for children under these conditions can be great allies in the search for care strategies that make them safer and learn to care for themselves ${ }^{(28)}$. In addition, it is recommended to work together between health professionals and education, seeking to ensure the maintenance of formal education and social interaction ${ }^{(25,33)}$.
Nursing training, which also appear in this review, involves actions that require different strategies. When students are able to relate knowledge and evaluate them, the information they understand takes on a broader and more efficient meaning. Learning to care through experiencing and problematizing in the chosen area and for self-interest are essential conditions for the exercise of freedom and autonomy, which are demonstrated in decision-making. Therefore, the student's involvement in his own training process, from his curiosity, improves cognition and produces more knowledge than the traditional method ${ }^{(34)}$.In this case, storytelling can be in the laboratories, in the real settings, and it is also possible for students to create texts and produce care for different situations. Learning to create and/or tell stories can help to discover the needs and situations of children that help in the therapeutic and care process.

In Brazil, the Diretrizes Curriculares Nacionais (National Curricular Guidelines) ${ }^{(35)}$ point to the change in teaching regarding caregiving practices, aiming to know the local reality. This means that teaching needs to consider practice settings, teaching methodologies and content selection, making students take responsibility for practice. Nursing students, when they use the therapeutic play in their activities, feel more autonomous and useful in the practice of nursing. Nurses learn to understand the emotional needs of children, approach them, and perform procedures with greater confidence and acceptance of children and families, which also occurred with the use of stories ${ }^{(36-25)}$.

Sophisticated technologies, including medicines, have led to a reduction in mortality and a progressive increase in chronic diseases. However, professionals are constantly challenged to create models of care that ensure efficacy for a growing and developing being and prevent diseases in childhood, adolescence and adulthood ${ }^{(37)}$. Storytelling is considered a simple, supportive and appropriate technology to assist children and families in the course of a grievance, be it acute or chronic. These technologies can also be used in the process of learning how to take care of children as, during training, the valuation of subjectivities is scored as important and necessary for human care. With this, it moves towards more participatory treatments and closer to what is expected of the concept of caring for.

The use of puppets and books proved to be a tool capable of producing care in the sense that they promoted more meaningful meetings, identifying needs through sensitive listening among nursing professionals and children and families. There was greater confidence and participation in the treatment and showed the particularities in each case, which is characterized as live work in act, approaching the concept of light technology in health, in a space predominantly hard technology ${ }^{(38)}$. It should be emphasized that the use of storytelling and/or literature advances in care, but must be accepted and developed in the teaching/learning of care in training, as it tries to break with the prescriptive and curative logic of the current care model.

\section{Study limitations}

Despite the quantitative of the productions found, only 16 articles met the inclusion criteria. This is due to the fact that in most of the material there is a predominance of the biological 
paradigm in child care. The low production of research with the theme of this review infers that there is a gap in the production of knowledge of this intervention/strategy of care in the area of the child.

\section{Contributions to the field of nursing, health or public policy}

Storytelling or use of books has accentuated and/or accentuates the care dimension, so often neglected in the current care model, since insofar as it focuses care in each case, in the child and in the family; it enriches and differentiates nursing work. In this sense, it can be a trigger for the construction of therapeutic projects, bonds and success in the participation of the child and the family, producing a type of differentiated and low cost nursing care.

\section{FINAL CONSIDERATIONS}

The search for articles that presented the use of stories in child care evidenced the situations in which it was used, such as: approach to a nursing procedure, venipuncture; preparation for surgery; reduction of anxiety in hospitalization; alternative therapeutic intervention to childhood cancer, coping with the consequences of chronic diseases and mental disorders in childhood; tool to initiate process of diagnosis and improvement in the treatment of HIV; understanding and improvement in the treatment of DM; humanization in the hospital; alternative tool of care teaching in course of graduation; in asthma-related health education and visual assessment; stimulating participation in the therapeutic process; and strategy of data collection in health research.

It was also possible to realize that the contributions of storytelling to children are many, such as learning, strengthening of bonds, reflection, solving doubts, capacity for interaction, creativity and imagination. It was evident that the stories are pertinent interventions/strategies in child care and qualify
Nursing, and may be associated with the therapeutic play. In addition, the stories provide an inclusive perspective, since even if the child does not move; they are relevant care tools and can be used with very sick children or with important physical limitations. Stories are capable of reducing stress, promoting bonding, and facilitating conversation about difficult situations, comforting, allowing play and being a tool for research in Nursing and in important situations in doing related to good care practices.

Situations dealt with the nursing care process in an expanded way, in hospitals, clinics, universities and schools. In addition, the stories were used in group and individualized assistance, through digital equipment, printed books, books to paint in the speech of the professionals who used the TP and also puppets. The stories of fairy tales were used in order to play and stimulate the imagination and the bond with the professionals, humanizing the nursing care. Specific stories of care were employed in a planned and structured way. Benefits provided added to those of fairytales, because in simple, accessible and ludic language, it was possible to intervene positively on needs that involved the health/disease process. Both have constituted important therapeutic resources and require further studies that best describe the differences. Thus, storytelling in the studies found was not compared to the practice of playing with other tools or TP, which also signals the importance of other researches.

As for the care model in which there was use of stories or tales, it was verified the intervention from the specific problems, in the contexts of the installed disease, but taking care of the needs of the children, widening the look on the care and respecting the time and the understanding of them.

Regarding the study settings, the infirmaries of children's hospitals were predominant. No evidence was found on the use of children's stories at children's home, Intensive Care Unit, Urgency and Emergency services, and Basic Health Unit. It still lacks studies that point out the nursing records from this intervention, as well as studies that interface with the nursing process.

\section{REFERENCES}

1. Alves CA, Deslandes SF, Mitre RMA. Desafios da humanização no contexto do cuidado da enfermagem pediátrica de média e alta complexidade. Interface. 2009;13(suppl 1): 581-94. doi: 10.1590/S1414-32832009000500010

2. Vessey JA, Mahon MM. Therapeutic play and the hospitalized child. J Pediatr Nurs. 1990; 5 (5) p. 328-33.

3. Oliveira CS, Maia EBS, Borba RIH, Ribeiro CA. Brinquedo Terapêutico na assistência à criança: percepção de enfermeiros das unidades pediátricas de um hospital universitário. Rev Soc Bras Enferm Ped. [Internet]. 2015 [cited 2018 May 10];15(1): 21-30. Available from: https:// sobep.org.br/revista/images/stories/pdf-revista/vol15-n1/vol_15_n_2-artigo-de-pesquisa-3.pdf

4. Brondani JP, Pedro EN. A story for children to help children with HIV understand the health-disease process. Rev Gaúcha Enferm. 2013;34 (suppl 1):14-21. doi: 10.1590/S1983-14472013000100002

5. Epstein I, Bonnie S, Mckeever P, Baruchel S, Jones H. Using puppetry to elicit children's talk for research. Nurs Inq. 2008;15(suppl 1):49-56. doi: 10.1111/j.1440-1800.2008.00395.x

6. Moura FM, Costa Jr AL, Dantas MAS, Araújo GCB, Collete N. Playful intervention with chronically-ill children: promoting coping. Rev Gaúcha Enferm. 2014;35(suppl 2):86-92. doi: 10.1590/1983-1447.2014.02.41822

7. Braga GC, Silveira EM, Coimbra VC, Porto. Promoção em saúde mental: a enfermagem criando e intervindo com histórias infantis. Rev Gaúcha Enferm. 2011; 32(suppl 1):121-8. doi: 10.1590/S1983-14472011000100016

8. Dale PSM, Pehrsson E. Bibliotherapy for Hospital Patients. J Hosp Librarianship. 2004; 4(suppl1): 73-81. doi: 10.1300/J186v04n01_07 
9. Merhy EE, Feuerwerker LCM. Novo olhar sobre as tecnologias de saúde: uma necessidade contemporânea. In: Mandarino ACS, Gomberg E. (org.) Leituras de novas tecnologias e saúde. São Cristóvão: [Internet]. 2009 [cited 2018 Mar 18]; Editora UFS. 285 p. Available from: http:// www.uff.br/saudecoletiva/professores/merhy/capitulos-25.pdf

10. Presidência da República. Casa Civil (BR). Subchefia de Assuntos Jurídicos. L № 8.069 (13 jul 1990). Dispõe sobre o Estatuto da Criança e do Adolescente e dá outras providências. [Internet] Diário Oficial da União: República Federativa do Brasil, 1990. Jul, 16 Seção 1: p. 13563 (Publicação Original). [cited 2018 May 02]. Available from: http://www.planalto.gov.br/ccivil_03/leis//8069.htm

11. Brondani JP, Pedro ENR. Educação em saúde com crianças: considerações a partir da literatura infantil. In: Felipe Asensi, Roseni Pinheiro e Paula Arévalo Mutiz (Org.). Bioética, trabalho e educação em Saúde. 1ed. Rio de Janeiro: Editora Multifoco, 2016, v. 1, p. $243-260$.

12. Hockenberry MJ, Wilson D. Wong - Fundamentos de enfermagem pediátrica. 9a Ed. Rio de Janeiro: Elsevier; 2014. 3092p.

13. Conselho Federal de Enfermagem, 546 R. Atualiza a Norma Técnica do brinquedo/brinquedo terapêutico pela Equipe de Enfermagem à criança hospitalizada. [Internet]. Diário Oficial da União: República Federativa do Brasil, 2017. May 17 Seção 1. p 136 N 93 . [cited 2018 May 21] Available from: http://www.cofen.gov.br/wp-content/uploads/2017/05/Resolu\%C3\%A7\%C3\%A3o-546-17.pdf

14. Mendes KDS, Silveira RCCP, Galvão CM. Revisão integrativa: método de pesquisa para a incorporação de evidências na saúde e na enfermagem. Texto Contexto Enferm. 2008;17(suppl 4):758-64. doi: 10.1590/S0104-07072008000400018

15. Yati M, Wahyuni S, Pratiwi DS, Islaeli. The effect of storytelling in a play therapy on Anxiety level in pre-school children during Hospitalization in the general hospital of Buton. Pub Health Indonesia [Internet]. 2017 [cited 2018 May 18];3(3):96-101 Available from: https://pdfs. semanticscholar.org/3adf/c002f89446ef9f19941e43ddd6766f9a9a86.pdf

16. Al-Yateem N, Brenner M, Shorrab AA, Docherty C. Play distraction versus pharmacological treatment to reduce anxiety levels in children undergoing day surgery: a randomized controlled non-inferiority trial. Child Care Health Dev. 2016; 42(suppl 4): 572-81. doi: 10.1111/cch.12343

17. Fontes CMB, Mondini CCSD, Moraes MCA, Bachega MI, Maximino NP. Utilização do brinquedo terapêutico na assistência à criança hospitalizada. Rev Bras Educ Esp. 2010;16(suppl 1):95-106. doi: 10.1590/S1413-65382010000100008

18. Silva JRS, Pizzoli LML, Amorim ARP, Pinheiros FT, Romanini GC, SilvaJG, et al. Using therapeutic toys to facilitate venipuncture procedure in preschool children. Pediatr Nurs [Internet]. 2016 [cited 2018 Apr 02];42(2):61-68. Available from: http://www.pediatricnursing.net/ce/2018/ article42026168.pdf

19. Castanha ML, Lacerda MR, Zagonel IPS Hospital: lugar para o enfermeiro cuidar do imaginário? Acta Paul Enferm. 2005; 18(suppl 1):94-9. doi: $10.1590 /$ S0103-21002005000100013

20. Albano MAS, Correa I. Lectura de cuentos infantiles como estrategia de humanización en el cuidado del niño encamado en ambiente hospitalario. Invest Educ Enferm [Internet]. 2011 [cited 2018 May 20];29(3): 370-80 Available from: http://www.scielo.org.co/pdf/iee/v29n3/ v29n3a05.pdf

21. Laing CM, Moules NJ, Estefan A, Lang M. Stories that heal: understanding the effects of creating digital stories with pediatric and adolescent/young adult oncology patients. J Pediatr Oncol Nurs. 2017;34(suppl 4):272-82. doi: 10.1177/1043454216688639

22. Braga GC, Kantorski LP, Coimbra VCC, Willrich JQ. Crianças e o conhecimento de si próprias a partir de histórias infantis Rev Enferm UFSM. 2015;5(suppl 2):327-38. doi: 10.5902/2179769214678

23. Sparapani VC, Jacob E, Nascimento LC. What is it like to be a child with type 1 diabetes mellitus? Pediatr Nurs [Internet]. 2015 [cited 2018 May 14]; 41(1):17-22 Available from: https://www.ncbi.nlm.nih.gov/pubmed/26281271

24. Kerry RS, Allister MM, Dwyer T, Krebs KL, Anderson C, Quinney L, et al. Little people, big lessons: an innovative strategy to develop interpersonal skills in undergraduate nursing students . Nurse Educ Today. 2014; 34(suppl 9):1201 -06. doi: 10.1016/j.nedt.2014.04.004

25. Coelho ACO, Marta DC, Dias IMAV, Salvador M, Reis VN, Pacheco ZML. Olho vivo: analisando a acuidade visual das crianças e emprego do lúdico no cuidado. Esc Anna Nery. 2010;14(suppl 2):318-23. doi: 10.1590/S1414-81452010000200015

26. Wyatt TH, Hauenstein EJ. Pilot testing okay with asthma: an online asthma intervention for school-age children. J Sch Nurs. 2008; 24(suppl 3):145-50. doi: 10.1622/1059-8405(2008)024[0145:PTOWAA]2.0.CO;2

27. Francischinelli AGB, Almeida FA, Fernandes DMS. Routine use of therapeutic play in the care of hospitalized children: nurses' perceptions. Acta Paul Enferm. 2012;25(suppl 1):18-23. doi: 10.1590/S0103-21002012000100004

28. Paula Diogo, José Vilelas. Os medos das crianças em contexto de urgência pediátrica: enfermeiro enquanto gestor emocional. Pensar Enferm[Internet]. 2016 [cited 2018 May 25];20(2):26-47 Available from: http://pensarenfermagem.esel.pt/files/Doc2_26_47.pdf

29. Souza M, Folquitto C, Oliveira M, Natalo S. Julgamentos em interpretações de histórias: uma abordagem piagetiana. Psico-USF [Internet]. 2008 [cited 2018 May 03];13(2):265-76. Available from: http://www.scielo.br/pdf/pusf/v13n2/v13n2a13.pdf

30. Rodrigues MC, Oliveira PA. Análise de livros infantis para a promoção de desenvolvimento sociocognitivo em pré-escolares. Estud Psicol. 2009;26(suppl 2):184-94. doi: 10.1590/\$0103-166X2009000200006

31. Ceribelli C, Nascimento LC, Pacífico SMR, Lima RAG. A mediação de leitura como recurso de comunicação com crianças hospitalizadas. Rev Latino-Am Enfermagem. 2009;17(suppl 1):81-7. doi: 10.1590/S0104-11692009000100013

32. Carreira D. $O$ direito à educação e à cultura em hospitais: caminhos e aprendizagens do Pequeno Príncipe. Curitiba [Paraná]: Associação Hospitalar de Proteção à Infância Dr. Raul Carneiro. [Internet]. 192p. 2016. Available from: https://pequenoprincipe.org.br/projetosabermais/ manual/Educ.pdf 
33. Borba RIH, Ribeiro CA, Ohara CVS, Sarti CA. O mundo da criança portadora de asma grave na escola. Acta Paul Enferm [Internet]. 2009;22(Especial - 70 Anos):921-7. doi: 10.1590/S0103-21002009000700015

34. Berbel NAN. As metodologias ativas e a promoção da autonomia de estudantes. Semina Ciênc Soc Hum. 2011; 32(suppl 1):25-40. doi: 10.5433/1679-0383.2011v32n1p25

35. Conselho Nacional de Educação. R. CNE 3. Institui diretrizes curriculares nacionais do curso de graduação em enfermagem. [Internet]. Diário Oficial da União: República Federativa do Brasil, 2001. Nov 9 Seção 1 p 37 [cited 2018 Apr 22]; 38p. Available from: http://portal.mec.gov.br/ dmdocuments/ces1133.pdf

36. Berteloni GMA, RKP, Bazzo APG, Ferrari RAP, Zani AV. Aplicação do brinquedo terapêutico em uma unidade pediátrica: percepções dos acadêmicos de enfermagem. Rev Enferm UFPE. 2013;7(suppl 5):1382-9. doi: 10.5205/reuol.3960-31424-1-SM.0705201317

37. Moreira MEL, Goldani MZ. A criança é o pai do homem: novos desafios para a área de saúde da criança. Ciênc Saúde Coletiva [online]. 2010;15(2):321-27. doi: 10.1590/S1413-81232010000200002

38. Merhy EE. A perda da dimensão cuidadora na produção da saúde: Uma discussão do modelo assistencial e da intervenção: no seu modo de trabalhar a assistência. In: Emerson Elias Merhy Sistema Único de Saúde em Belo Horizonte: reescrevendo o público; Ed. Xamã; [Internet]. São Paulo, 1998. [cited 2018 Jun 03] 24p. Available from: http://www.uff.br/saudecoletiva/professores/merhy/capitulos-10.pdf 